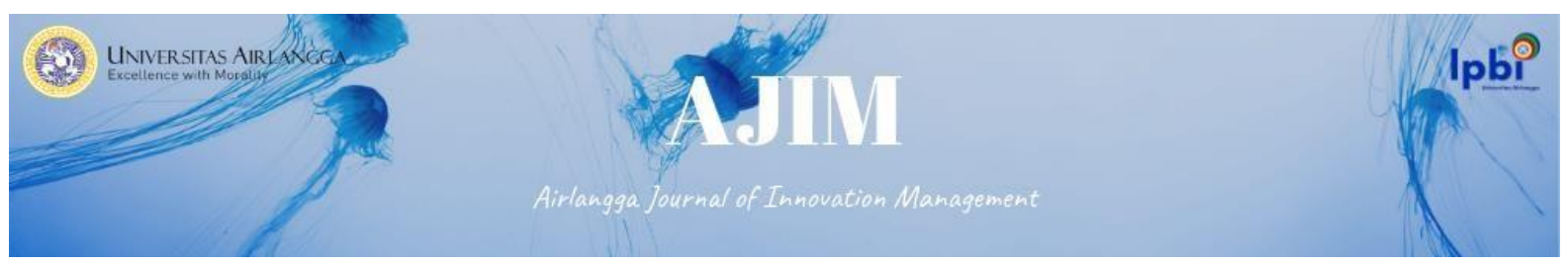

Vol. 2 No.2 Oktober 2021

e-ISSN: 2722-5062

DOI : 10.20473/ajim.v\%vi\%i.31073

\title{
THE STUDY OF SME'S PERFORMANCE IN FURNITURE CARVING INDUSTRY
}

\author{
Tri Siwi Agustina* \\ Department of Management, Faculty Economic and Business, Universitas Airlangga \\ *Corresponding e-mail: tri-s-a@feb.unair.ac.id
}

\begin{abstract}
The center of SMEs carving furniture in Karduluk village, Sumenep Regency in Madura, East Java which has dynamic and uncertain environment and also high level of competition. Such situation needs adequate managerial capabilities so that SME players can sustain their existence from external competition. In spite of its thriving existence, the industry has some potential problems, which need to be identified The purpose of this research is to determine the effect of the entrepreneurship orientation, the capability of business network towards the performance of SMEs through the commitment of the businessmen. This research employed quantitative analysis, which used AMOS as its method of analysis. Data collection was conducted by distributing questionnaires to 105 craftman who were also managers of craving furniture units. This research found that businessmen orientation affected the performance of carving furniture. Business networking capability affected the performance of carving furniture. Behavioral commitment had a partial mediation impact on entrepreneurship orientation towards the performance of carving furniture. Behavioral commitment had a full mediation impact on entrepreneurship orientation towards the performance of carving furniture.
\end{abstract}

\section{Keywords: Behavioral Commitment; B usiness Networking Capability, Craving F urniture Industry, Entrepreneurship Orientation, SME's Performance}

\section{Introduction}

Indonesian government focuses on preparing SME players in order to improve competitiveness and engage in cooperation with other players from ASEAN. By enhancing their capacity, it is expected that Indonesian players can take advantage from the market and at the same time. Entrepreneurship process contains attitude and behavior components, Attitude represents an individual or organization willingness to take new opportunities and to take responsibility to influence a creative change. This willingness often refers to entrepreneurship orientation. Dess \& Lumpkin (1996) proposed that the entrepreneurship orientation represents entrepreneurship process and also related to newly operated venture (Quince, 2003).

This research was conducted on the center of SMEs carving furniture in Karduluk village, Sumenep Regency in Madura, East Java which has dynamic and uncertain environment (related to competitor, supplier, regulator, and business association), and also high level of competition (related to price, product, technology, distribution, human and natural resources). Such situation needs adequate managerial capabilities so that SME players can sustain their existence from external competition 


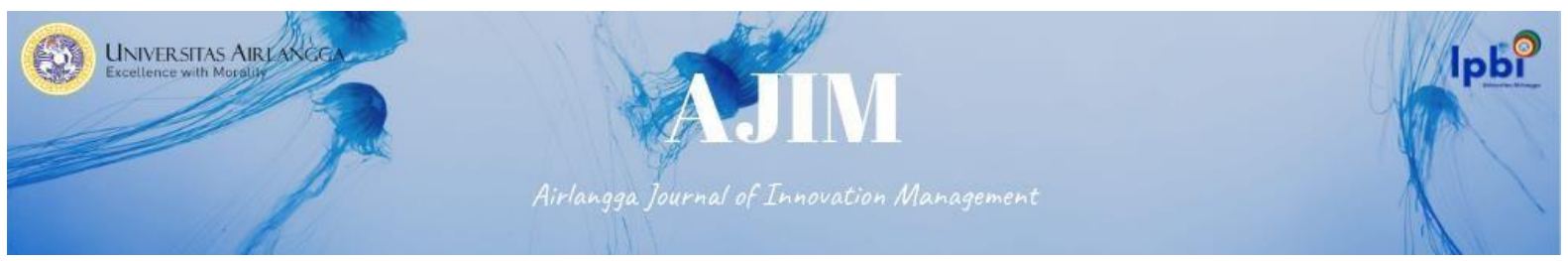

Research about product was including traditional and modern style. It is important to maintain this variation in order to compete with other company outside this region. Until present time, the development of this industry could reduce unemployment, since this industry needs a largenumber of employee. Furniture that produced by SMEs in this regency are cabinets, couches, chairs and other items made from wood. All of these products are varied in the shape and size. Mostof the businessmen in this center of SMEs in Karduluk village already has market either domestic or international market.

There are some obstacles faced by the SMEs, including competitors from outside Karduluk village, insufficient capital and inadequacy of teak wood supply for production. Government through their relevant agencies and also local government provided assistances to solve these problems. Such efforts include coaching on carving technique, furniture durability and marketing. Coaching held byrelated agency focused on carving technique, furniture durability, and marketing. However, coaching itself is insufficient to support the business. Instead, strong commitment to strive for sustaining business is essential.

Related to those research questions, this study aims to explore the direct influence of entrepreneurship orientation and business networking capability towards the performance of carving furniture and also the indirect influence of entrepreneurship orientation and business networking capability towards the performance of carving furniture through behavioral commitment. Moreover, this study expect to contribute to the enrichment of knowledge in relevant field as well as on operational practical issues.

\section{Literature Review}

Entrepreneurship orientation is a character of the entrepreneurs which characterizes the unyielding nature, risk-taking attitude, speed and flexibility (Liao and Sohmnen, 2001). Entrepreneurial orientation emphasizes on passion to create innovative businesses as a refresher of congestion businesses, which often accompany the initial steps of innovation (Zhou et al, 2005). In the other words, it is essential to be proactive towards new opportunities, support the company capability to create new products, and not only one step ahead to compete with competitors but alsoone step ahead to understand customers need (Slater and Naver, 1994).

Business network is a variable which considered as essential for all kind of business, especially due to the fact that that economic environment became very competitive. Hackanson (1997) states that business network is important for the company in 4 areas, including managerial area, entrepreneurship activities, technology development, and customer relationship. Such networks can rely on personal contact and trust between individuals and can provide complementaryresources and reduce the risk of opportunistic and reduce transaction costs (Granovoter, 1985).

Behavioral commitment is a commitment as of individual commitment towards their job as businessman. SME business players are deemed to have strong commitment, determination and be willing to give all attention to their business, so that half-hearted attitude might bring them business failure (Lowe dan Ziedonis,2006).

SME's Performance variable is performance of small and medium enterprises. Performance is a multidimensional concept, and the relation between entrepreneurship orientation and performance depend on indicators used to assess performance (Dess dan Lumpkin, 1996). Previous studies show that there are differences on performance indicators, which usually reflect thedifferences between the size of financial and non-financial performance (Combs, Crook dan Shook, 2005). Generally it is the difference between the size of the financial and non-financial performance. The measurement of non 


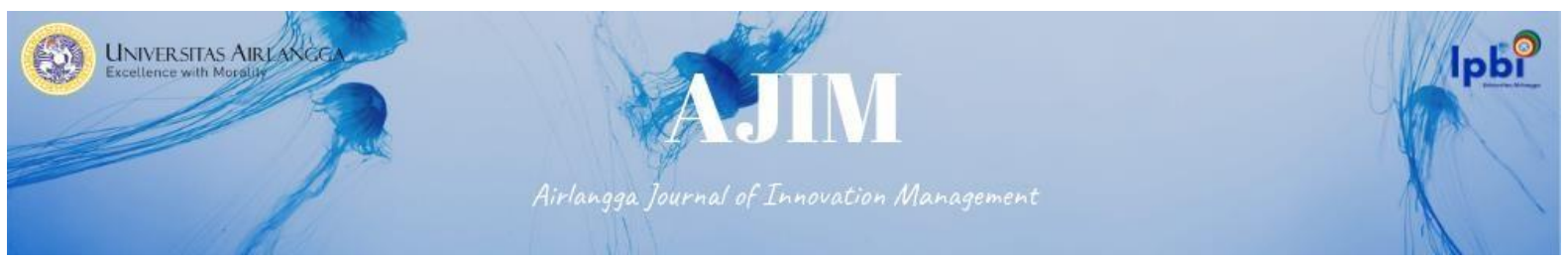

financial performance includes measurement of business goals such as satisfaction and the successful level in the global scope that can be achieved by the owners or managers. Meanwhile to measure the financial performance, somefactors such as sale growth and ROI are measured.

\section{Hypothesis Formulation}

Lee and Tsang (2001) conduct a research about the impact of entrepreneurship orientation which consists of need of achievement, internal locus of control, self reliance and extroversion towards venture growth such as sales growth and profit. Covin and Slevin (1986) state that there is a relation between entrepreneurship posture (which measured with risk taken, product innovation, and proactive attitude) and the company's performance. Zahra (1991) finds that there is a positive relation between entrepreneurship orientation with profitability and growth. This findingsis similar with the finding of Smart and Conant (1994) that there is a significant relation betweenentrepreneurship orientation and profitability as well as performance. Based on these previous research, this research proposes that:

\section{$\mathrm{H1}$ :There is a direct effect of entrepreneurial orientation on the performance of carving furniture}

A close relation with supplier will give strong contribution to the performance improvement ofthe company through cost efficiency, quality improvement, reliability, and availability of input at all time. On the other hand, supplier could enhance information regarding market development, newtechnology, and competitor movement (Terziovski, 2002). Previous research finds pro and contra regarding the effect of business network towards SME's performance Some research found that business networking capability has positive effect on the performance of the company, while other research find that business networking capability has no effect on the performance of the company (Batjaragal, Bat, 2000). Aldrich (2000) states that network capability does not automatically enhance the performance of the company. Therefore, based on earlier researches, it can be hypothesized that:

$\mathrm{H} 2$ :There is a direct effect between network capability towards the performance of craving furniture

Timmons (1994) proposes that entrepreneurship process is a driving process of the emergence of opportunities. These opportunities was conducted by the group of entrepreneurs, and attributed by efficient use of resources. Moreover, Hortovanyi (2009) proposes that entrepreneurs managers formally committed to exploit opportunities available, and needed to overcome problems caused by the gaps of abundant resources (or lack of resources). At the end, they should able to employ these resources to motivate their team to moving forward by overcome the problem of resources gap. Based on the result of previous research, it could be hypothesized that:

H3 : There is indirect effect between entrepreneurship orientation towards the performance of craving furniture through behavioral commitment.

Managers and entrepreneurs must be well skilled in relationships with people who are important to the success of their business (Cook, 1992; Larson dan Star 1993). Moreover, entrepreneurs are needed to make strategic choice related to their networks in order to build new relations and also improve the weak ones or for extreme cases, terminate relationship with the network based on the change of company's needs (Elfring and Hulsink, 2007; Hite, 2005; Larson and Star 1993; Szabo, 2007). In conclusion, people with good relations has ability to mobilize their network resources effectively to achieve company's target of performance, compared to people or groups who have weak social 


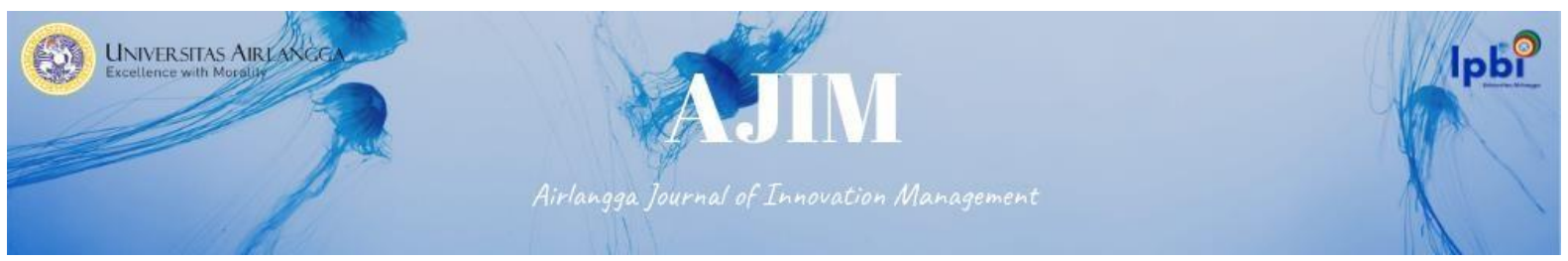

relations. According to Voerman (2003), aspects affecting export performance is behavioral commitment of resources or numbers of resources needed to conduct export activities In addition, as stated Evangelista (1994), attitudinal commitment towards actual behaviour (in the form of fund allocation, journey undertaken and other activities) could improve managers satisfaction through export activity. Based these studies, it can be hypothesized that:

H4 : there is indirect effect between network capability towards the performance of carving furniture through behavioral commitment.

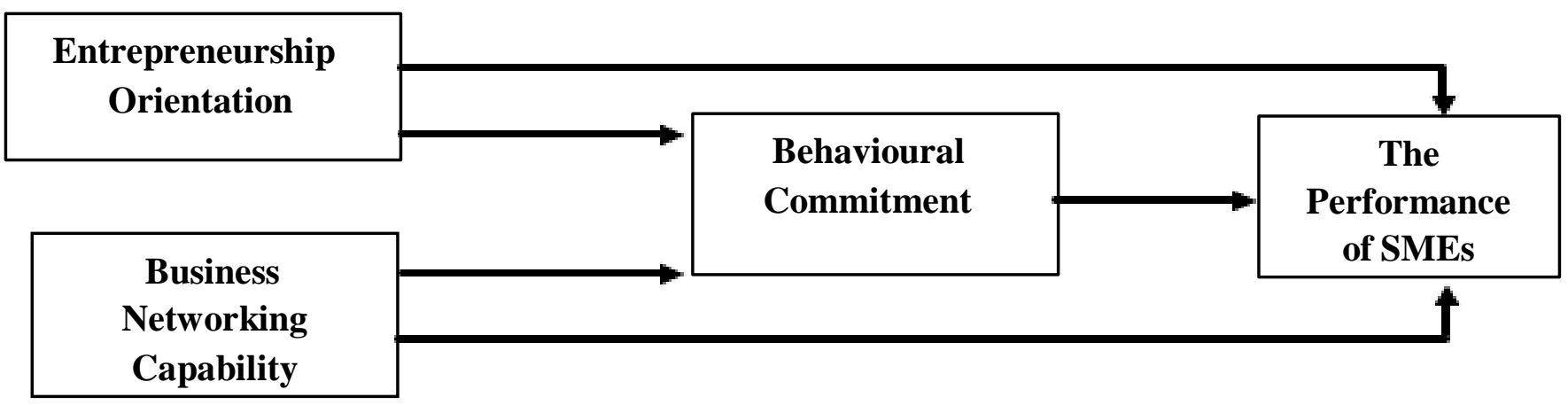

Figure -1

Source: Research Process (2021)

\section{Methods/Materials}

The population of this research was all entrepreneurs who are also the owner and manager of carving furniture SMEs in Karduluk Village, Pragga District, Sumenep Regency, Madura. The next criteria was appointed based on Law No. 20/2008, and whether company has export orientation. The number of carving furniture SMEs in that village are 130businessmen and 105 of them doing export. Therefore sampling conducted by doing census since all members of population were taken as research respondent.

The first exogeneous variable in this research is Entrepreneurial orientation is a character embedded in businessmen who is also manager of carving furniture SMEs in Karduluk Sumenep. This character has an attribute of unyielding, risk-taking, speed and flexibility attitude. In this research, the dimension of entrepreneurial orientation employed is based on empirical dimension employed in the research of Lee and Tsang (2001:599). In order to measure entrepreneurial orientation, some dimensions were employed, such as Need for Achievement, Internal Locus of Control, Self Reliance dan Extroversion.

The second exogeneous variable in this research is business networking capability, which represents ability to establish network with other parties. In this research, dimension of business networking capability was based on empirical dimension employed in research conducted by Winklund (1999). Based on that research, there are three subjects in entrepreneurial network, which are family, friend and acquaintance who will support the company to get information. Supporting network consists of agents, bank, government, university, and networking between companies.

As for an endogeneous variable, which also acts as mediating variable is behavioral commitment. It represents strong determination of the owners as well as managers of carving furniture SMEs, who devote all his attention on the business being operated. In this research behavioral commitment dimensions were based on research conducted by Voer man (2003), 


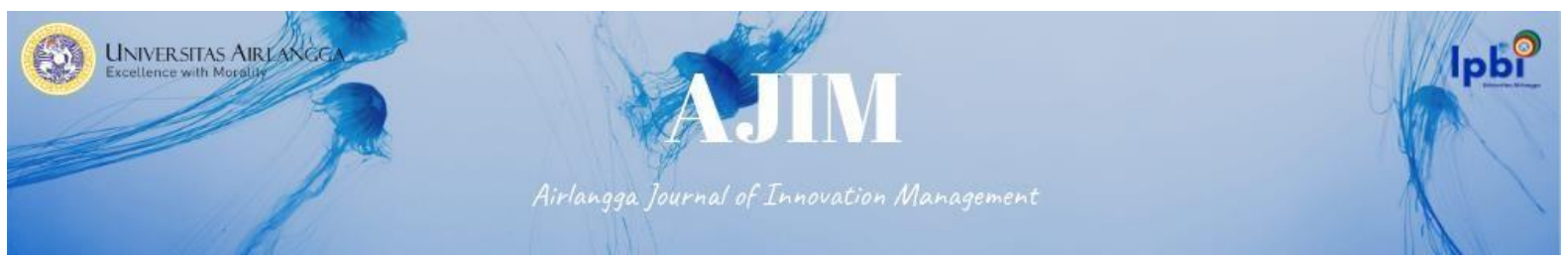

which are planning, information gathering and information utilization, human resources empowerment.

Another endogenous variable in this research is SME's performance. SME's performance is defined as the work accomplished by the owner as well as manager of carving furniture SMEs in Karduluk Sumenep to develop their organization. Respondents were asked to compare their performance in 8 (eight) questions. In this research, dimensions were adapted from several previous research, in which SME's performancedimension utilized was based on research conducted by Baker and Sinkula (1999), based market share relative change was adapted from Day (1997), and market and customer growth was adapted from Narver and Slater (1990). Respondent's response toward entrepreneurship orientation variable, business networking capability variable, and SME's performance variable was measured using Likert scale, where (1) represents strongly disagree, (2) represents disagree, (3) represents moderately agree,(4) represents agree, (5) represents strongly agree.

Primary data was collected using questionnaire which has passed the reliability and validity test. These tests is important in order to confirm the consistency and accuracy of data collected from the instrument. Moreover, to test the hypotheses and to generate a fit model, analysis was held using SEM (Structural Equation Models), supported by AMOS ver. 16 application. This model was employed because there is tiered relationship structure between variables, and there is unobservable relations which affected variables

\section{Results and Discussion}

Table 1 below shows respondent's profile in carving furniture SMEs in Karduluk village, Sumenep, Madura.

Table 1.

Respondents Characteristics

\begin{tabular}{|ll|ll|}
\hline 1. & Age & 35 years old - 68 years old \\
\hline 2. & Gender & - & 98 Male \\
& & - & 7 Female \\
\hline 3. & Education Level & - & 49 people finished Senior High School/the same level \\
& & - & 20 people finished Diploma/the same level \\
& & - & 31 people finished Bachelor/the same level \\
& & 5 people finished Junior High School and Elementary School \\
\hline 4. & How long the business & 9 years until 28 years \\
& has operated & \multicolumn{2}{|l|}{} \\
\hline 5. & Number of Employees & $5-15$ employees \\
\hline 6. & Business Experience \\
& andKnowledge & - & 53 people got knowledge from family \\
& & - & 30 people learned by himself (started from zero) \\
& & & 22 people are used to work in the carving furniture company \\
\hline
\end{tabular}

Source: Processed by Researchers 


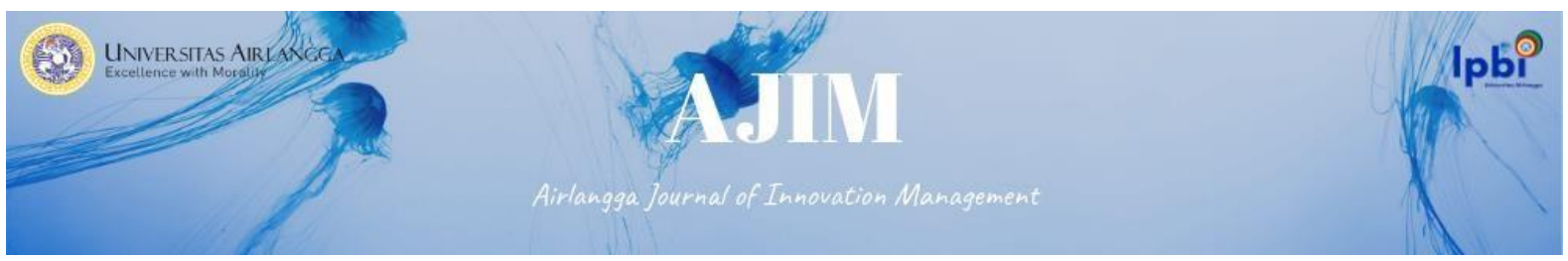

Items in the questionnaire are proved to be valid if the value of corrected item total correlation( $\mathrm{r}$ value) is higher than 0.3 ( $\mathrm{r}$ value $>0.3$ ). Moreover, the questionnaires are proved to be reliable if the Cronbach's alpha value for each variable is higher than 0.6 . Validity and reliability test are appliedto the questionnaire with 30 samples. Based on the result of the test, all questions in the questionnaire has proved to be valid and reliable.

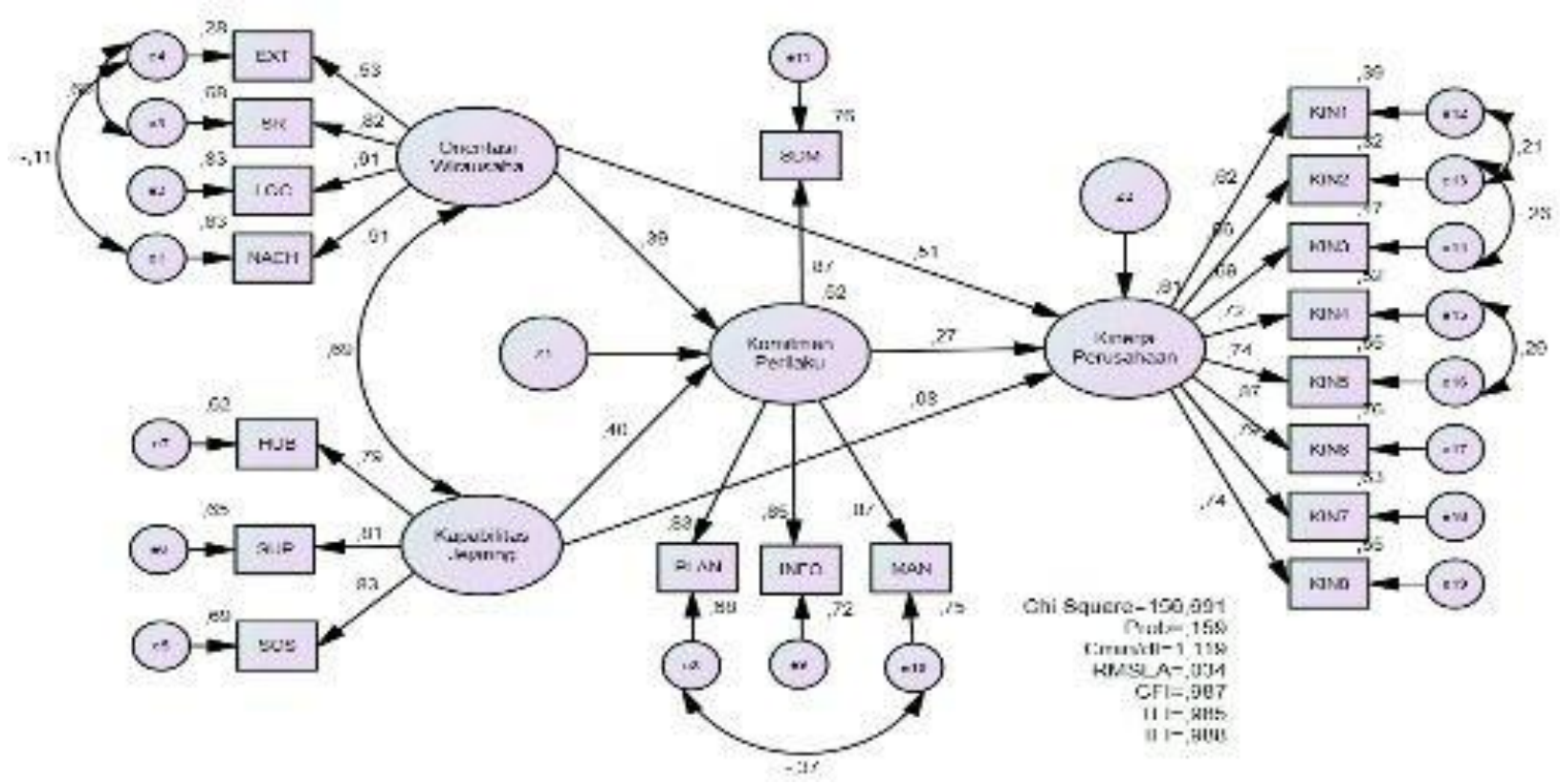

Figure2

Structural Equation Model (SEM) Analysis Result

Source : Research Result (2021)

\section{Explanation :}

OrientasiWirausaha $=$ Entrepreneurship Orientation $;$ KapabilitasJejaring Usaha $=$ Business

Networking Capability ; KomitmenPerilaku = Behavioral Commitment $;$ Kinerja Perusahaan = The performance of SME.

Table 2 Conditions of Model Fitness

\begin{tabular}{|l|c|l|}
\hline \multicolumn{1}{|c|}{ Critera } & Accepted Condition & \multicolumn{1}{c|}{ Result } \\
\hline Chi Square & $<$ Chi Square Tabel $(168,613)$ & 156,691 \\
\hline Probability & $>0,05$ & 0,159 \\
\hline Cmin/df & $<2,00$ & 1,119 \\
\hline RMSEA & $<0,08$ & 0,034 \\
\hline CFI & $>0,95$ & 0,987 \\
\hline TLI & $>0,95$ & 0,985 \\
\hline IFI & $>0,95$ & 0,988 \\
\hline
\end{tabular}

Source : Research Result (2021) 


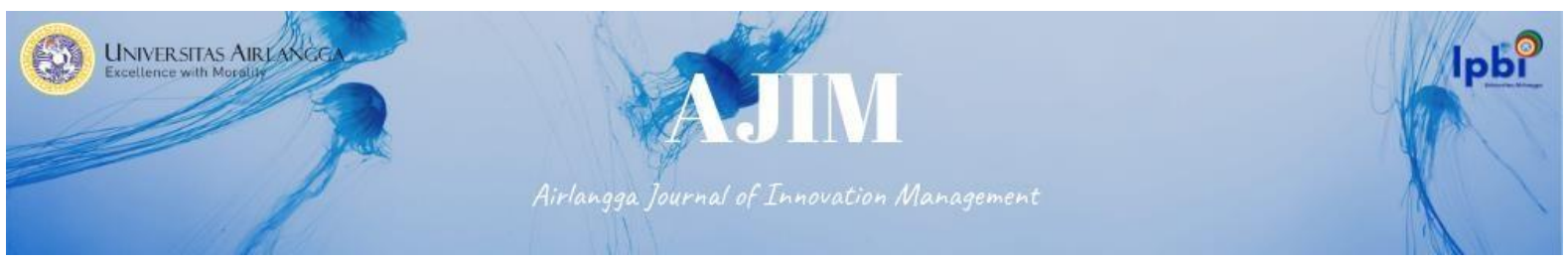

Table 2 shows that all constructs utilized in this research model. On the full model SEM analysis, it can be seen that the model fulfilled goodness of fit criteria. It can be seen in the tablethat the value of Chi Square is 156.691, which is lower than determined cut-off value (168.613). With the value of probability 0.159 , which is above 0.05 , it can be said that there is no difference between estimated sample covariance matrix and estimated population covariance matrix. Other goodness of fit criteria also shows accepted condition, where Cmin/df $(1,119)$, RMSEA $(0,034)$, CFI $(0,987)$, TLI $(0,985)$ and IFI $(0,988)$. Therefore, SEM model in this research is adequate to test the hypotheses.

Causality relationship developed in the hypothesis in this model needs to be tested by testing null hypothesis, in which there is no difference in the interrelationships regression coefficient with null condition. T-test was held to test this condition just as the test in the regression analysis. CR statistical value need to have t distribution with $95 \%$ degree of freedom. The hypotheses result can be seen as follows

Table 3

\section{Regression Weights: (Group number 1 - Default model}

Source : Research Result (2021)

\begin{tabular}{|c|l|lllll|}
\hline \multicolumn{2}{|l|}{} & Estimate & S.E. C.R. & Pabel \\
\hline Behavioral_Commitment & K--Entrepreneurship_Orientation &, 490 &, 156 & 3,148 &, 002 \\
\hline Behavioral_Commitment & K-- Networking_Capability &, 501 &, 162 & 3,087 &, 002 \\
\hline Company_Performance & K-- Behavioral_Commitment &, 189 &, 084 & 2,252 &, 024 \\
\hline Company_Performance & <--Entrepreneurship_Orientation &, 451 &, 121 & 3,721 & $* * *$ \\
\hline Company_Performance & K-- Networking_Capability &, 074 &, 112 &, 665 &, 506 \\
\hline
\end{tabular}

Tabel 4 Standardized Regression Weights

\begin{tabular}{|c|l|l}
\hline \multicolumn{2}{|l|}{} & Estimate \\
\hline Behavioral_Commitment & K--Entrepreneurship_Orientation &, 388 \\
\hline Behavioral_Commitment & K-- Networking_Capability &, 399 \\
\hline Company_Performance & K-- Behavioral_Commitment &, 270 \\
\hline Company_Performance & K--Entrepreneurship_Orientation &, 510 \\
\hline Company_Performance & K-- Networking_Capability &, 084 \\
\hline
\end{tabular}

Source : Research Result (2021)

The value of probability is 0.510 , which is higher than $5 \%(0.510>0.05)$, meanwhile the value of path coefficient is 0.000 . It means entrepreneurship orientation has a direct, significant, andpositive effect towards performance of SMEs. Therefore, hypothesis 1stating that entrepreneurship orientation has direct effect on the performance of craving furniture SMEs was accepted. The value of probability is 0,084 , which is higher than $5 \%(0,084<0,05)$, meanwhile the value of path coefficient is 0,506 . It 


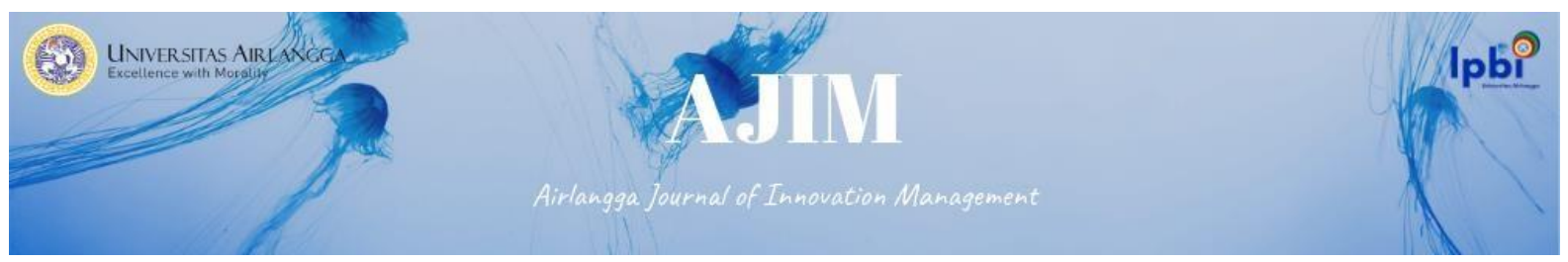

means business networking capability does not have direct, positive and significant effect towards performance of SMEs. Therefore, hypothesis 2 stating that business networking capability has direct effect on the performance of craving furniture SMEs was rejected. The influence test result between entrepreneurship orientations towards company performance based on SEM model shows that influence value is 0.510 with $\mathrm{p}$ value of 0.000 . Therefore, it can be concluded that the influence is significant. The influence value between entrepreneurship orientations towards behavioral commitment is 0.388 with $\mathrm{p}$ value of 0.002 . Therefore, it also can be concluded that the influence is significant. So as the influence of behavioral commitment towards SME's performance, which the influence value is 0.270 and with $\mathrm{p}$ value of 0.024 , which shows significance of the relations. Therefore, it can be concluded that the mediating character of behavioral commitment is partial mediation. In other words, entrepreneurship orientation has direct influence towards SME's performance without involving behavioral commitment. Therefore, hypothesis 3 stating that entrepreneurship orientation has indirect effect on the performance of carving furniture was accepted. The influence test result between business networking capability with company performancebased on SEM model shows that influence value is 0.084 with $\mathrm{p}$ value of 0.506 . Therefore, influence is not significant. The influence test result between business network capabilities towards behavioral commitment is 0.339 with $p$ value of 0.002 . Therefore, it can be concluded that the influence is significant. The same significant result was also shown by the influence of behavioral commitment towards company performance with the influence value of 0.270 and the $\mathrm{p}$ value of 0.024 . Therefore, it can be concluded that behavioral commitment has character of full mediation, or it can be said that entrepreneurship orientation does not have direct and significant effect towardscraving furniture SMEs in Karduluk, Madura without involving behavioral commitment. Therefore, hypothesis 4 which stated that business networking capability has indirect effect towards the performance of carving furniture through behavioral commitment can be accepted.

The study shows that entrepreneurship orientation has positive and significant effect towardsthe performance of SMEs operated by the owner which also became manager in carving furnitureIt has been proved entrepreneurship orientation can influence company asset improvement, company profit improvement, as well as the improvement of sales volume,employee utilization growth, financial performance, domestic and international market enhancement.Internal Locus Control (LoC) dimension and Need for Achievement (N. Ach) dimension are dimensions with the highest loading factor. These dimensions representing the character of Madura people which are tenacious, hardworking and unyielding in doing their business. One example aboutNeed of Achievement of carving furniture SMEs is their readiness to take big job regardless whether it is over their usual capacity.

Besides the individual character, religion, which in this case is Islam has strong influence towards the working ethic of Madura ethnic. As well known, Madura ethnic has strong Islamic value. Therefore, this Islamic value became their working ethic value. In Islam, working is a part of human nature as well as human identity. Through working, human honors themselves; hence, lazy people and those who do not have willingness to empower their potential ability are considered as those against their own nature and dishonor themself. Theoretical finding in this study supported previous theory found by Lee and Tsang (200), Covin and Slevin (1986), Zahra (1991), Smart and Conant (994).

The result of this study showed that business networking capability does not have significant influence towards the performance of carving furniture SMEs in Karduluk Sumenep which were operated by owners/managers. It means the enhancement of company's asset, company's profit, company's sales volume, company's growth of employee utilization, company's financial performance, company's domestic and export market growth were not fully influenced by company's networking capability in order to acquire resources needed, such as information, money, and moralsupport. The 


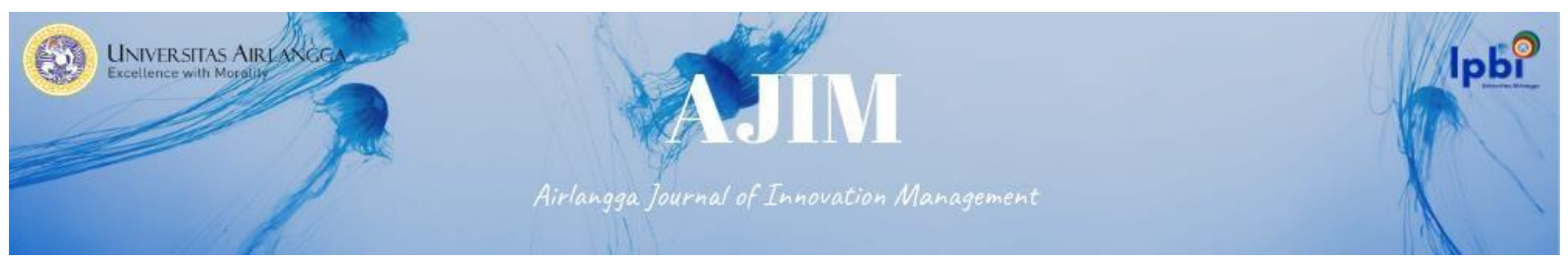

theoretical finding in this study supported previous theory found by Batjaragal, Bat, (2000) and Aldrich (2000), which explained that network capability does not automatically influence the performance of the company.

From the observation, it was found that business networking capability did not have real impact towards entrepreneurship orientation on the SME's performance. This situation occurred due to uneven supports from various parties who assist the development of carving furniture SME's business in Karduluk village. Support from social actor is a dimension with highest loading factor in forming business networking capability. Hence, it can be said that even though there is a big support whether in the form of information or financial support that came from family, friends, or acquaintance, but the support that came from supporting system (government, bank, association anduniversity) as well as support from other companies were uneven.

In particular, strong support that came from family, friends, and acquaintances was not enough to enhance the determination and tenacity of carving furniture SMEs entrepreneurs in order to improve the SME's performance. If we linked this phenomenon with respondent's characteristics as described in Table 4, it can be described that the majority of carving furniture businessmen aremale. As the head of the family, they have role as the breadwinner to fulfill the needs of their family. As entrepreneur, the profit or loss gained from their business will affect their revenue. Therefore,strong determination and tenacity was needed in order to do well in both roles. In order to enhance the performance of SMEs, the support needed are not only in terms of information and financialsupport, but also other kind of supports such as energy and thought.

It is found that strong support from local government (in this case the local government refersto Sumenep Regional Cooperative and SMEs Services) in the form of evaluating entrepreneurs and managers of carving furniture SMEs did not adequately supported by association, bank, and university.

The result in this study shows that entrepreneurship orientation has an indirect effect towardsthe performance of carving SMEs in Karduluk village through behavioral commitment. Mediation character of behavioral commitment variable is a partial mediation. Hence, it can be interpreted that entrepreneurship orientation has direct impact towards the performance of carving furniture SMEs in Karduluk village, without involving behavioral commitment variable. It means there areother variables that were excluded in this research that might have potential as the mediation between entrepreneurship orientation and SME's performance. It can be implied that business experience and knowledge were gained or heredited from their ancestors or family who hd previous experiences of working as employees of carving furniture company in the same region.

Based on respondent's answer, behavioral commitment can not take role as mediating variable between entrepreneurship orientation and SME's performance. This situation occurred due to several causes such as planning activity. Most of the businessmen did not develop adequate planning or feasibility study before they do their business. This is in contrast with respondents answer which mentioned that there was strong support from Sumenep Regional Government (in thiscase the local government refers to Sumenep Regional Cooperative and SMEs Services) by providing business plan training. Therefore, it can be concluded that most businessmen appreciate the support provided by local government, but they cannot implemented what has been taught to them in the real business life. Simple financial calculation was regarded to be more important for them, so that they know how to calculate their profit and their business did not gained loss. Another factor considered as an important factor for the businessmen is the marketing opportunity as well asthe availability of raw material. The SMEs businessmen thought that it is useless to have business ifthey do not have market. Hence, they only 


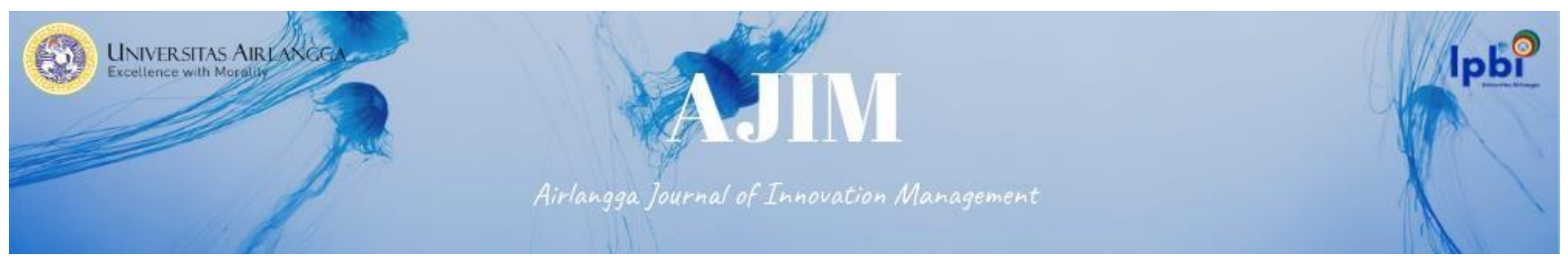

focus on short term planning and simple profit-loss calculation, instead of analyzing long term potential demand of products and services.

Based on the interview result, it was revealed that there was local government support towards the development of market export. However, this support did not significantly improve the performance of SMEs because businessmen could not perform the export by themselves. Businessmen usually export their products through the assistance of exporter. Respondents expectedthat they could get training about how to export their product.

The result of this research showed that business networking capability has indirect effect towards SME's performance in Karduluk village through the involvement of behavioral commitment. The mediation character of behavioral commitment variable is a full mediation. Therefore, it can be interpreted that behavioral commitment is absolutely necessary by business networking capability variable to improve the performance of SMEs, since business networking capability itself does not have a direct and significant effect on improving the performance of carving furniture SMEs in Karduluk villages without influencing behavioral commitment.

The dimension of social actor support is a dimension with the highest loading factor in forming business networking capability. Family supported the business by providing information and knowledge transfer that were given by parents or husband as the founder of the carving furniture business. As observed in the field, the majority of carving furniture business managers in Karduluk is the successor of the business.

Result showed that although businessmen were enthusiastic towards development program held by Local Government, the implementation was poor. This situation occurred due to the lack of time and energy to think about long-term strategic matters. In order to overcome this problem, businessmen could maximize the role of their social support, including family, by involving them further on the development of business planning as well as the search of business information.

At present time, carving furniture SMEs in Karduluk village realized that at the current competition situation, the speed to get information is essential. Based on information gathered from interview, in 1970, there were only 15 carving furniture entrepreneurs, nowadays there are 150 entrepreneurs even though not all of them has export orientation. The market also experienced vast growing. Now the market does not only cover domestic market, but also international market, such as European countries, Malaysia, Japan, Dubai, and small number of SMEs exported their product to US. For domestic market, many of carving furniture SMEs in Karduluk village that became permanent supplier for furniture industry in Rembang, Jakarta, Pasuruan, and some other cities in Sumatra and Sulawesi. Considering this situation, information was fully considered as substantial factor in improving the performance of SMEs, especially to expand the number of customers. This can be seen from information utilization indicator which has highest loading factor in the forming of behavioral commitment and customer growth dimension.

This research has limitations, in which that it was conducted only in carving furniture SMEs on Karduluk village. It disregards other backgrounds such as businessman's activities, length of time the business has been operating and also cultura background that might have effect on the SME's capability. There was also a limitation in terms of respondent's perception on the questions due to language factor that caused not all questionnaire was answered directly correspond with businessman or business owner's perception 


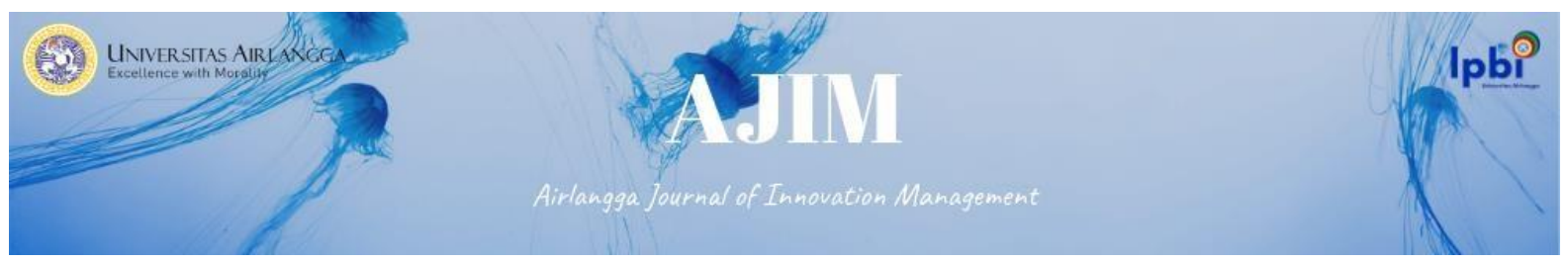

\section{Conclusion}

This study was able to conclude several points. First, Entrepreneurship orientation has direct effect to performance of carving furniture. Second, business networking orientation does not have direct effect to performance of carving furniture Third, entrepreneur's orientation improvement will give bigger impact if involving improvement of entrepreneur's behaviorall commitment. Fourth, business networking improvement in order to improve performance of carving furniture will give bigger impact if involving improvement of entrepreneur's behavioral commitment.

The result of this research shows that behavioral commitment cannot play role as mediator between entrepreneurship orientation and the performance of carving furniture SMEs in Karduluk village, Sumenep. Therefore, it is suggested that businessmen could strengthen their commitment by developing business plan with clear purpose for longer business term. It means that business plan are not only orientated on day to day operation. As for the local policy maker of SME's development it was suggested that the organization development program also followed by mentoring activities inorder to make sure that the developed plan will be adequately implemented. By this, it is expected that carving furniture SMEs have a better understanding regarding the development of business plan, and the discipline of developing the plan in each business stage. With regard to developing export market, it is better that government keep the coaching and mentoring activities, so that businessmen dare to export their own product instead of depending on the assistance from exporter as experienced at the present time.

The improvement of business networking capability in order to improve the performance of carving furniture SMEs in Karduluk village will give a bigger impact if involving the improvement of behavioral commitment. Therefore, it was suggested that entrepreneurs and manager of carving furniture SMEs could delegate their working load to their family and their employee. They should be able to train their family and employees so that they can focus more on the development of business plan, and the improvement of their companys performance. As for the local policy maker regarding the SME's development, it is suggested that they can adequately facilitate the strong will of carving furniture SMEs businessmen to develop their business and market. Some suggested facilitation activities is that local government could empower entrepreneursby developing their production technique, their ability to understand foreign language so that they can directly meet their foreign buyer. Moreover, supports from the government in the term of legal framework are also very important to ensuring the availability of raw materials (teak wood). What happened is that the wood/log were commercialized as goods for import purpose, therefore it hampered the overall carving furniture production process.

For further research, this study can be used as a reference for subsequent theoretical and empirical studies, especially regarding entrepreneurship orientation, business networking capability, behavioral commitment, and the impact of all of these variables toward the performance of SMEs by involving other variables excluded in this research which might affecting the improvement of SME's performance Those variables might came from internal or external business environment, such as management commitment, culture, business strategy, competitive advantage, experience, and business knowledge. It is also suggested that future research might be conducted by focusing more on particular scale such as micro scale only, or small or medium scale so that the results can bemore specific and suitable for each business scale.

\section{References}

Aldrich, R and Baker, T (2000), Blinden the Cities? Has There Been Proggress in The Entrepreneurship Field ? In D Sexton and R Smilor (Eds), Entrepeneurship 2000, Chicago : Upstart Publishing Company 


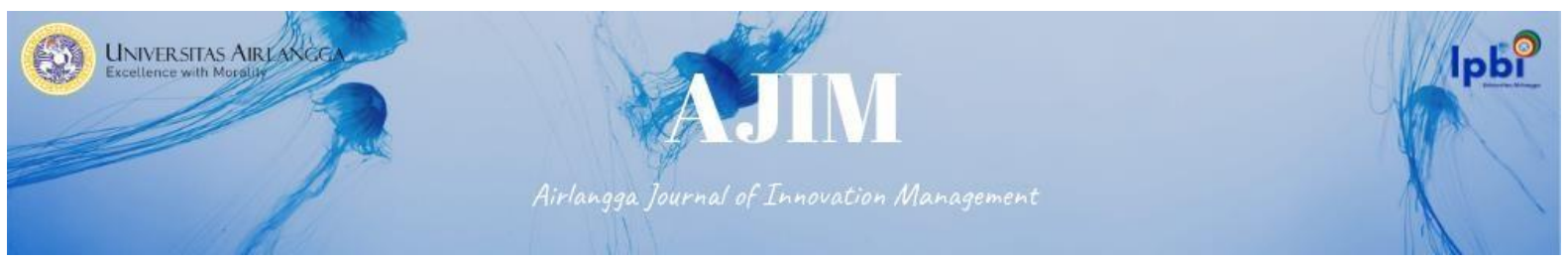

Becker,G (1964) Human Capital, New York, Columbia University Press.

Baker, W. E., \& Sinkula, J. M. (1999). The synergistic effect of market orientation and learning orientation on organizational performance. Journal of the academy of marketing science, 27(4), 411-427

Cook, W. M. (1992). The buddy system. Entrepreneur, Nov, $52 .$.

Day, G. S. (1997). Aligning the organization with the market. Reflections on the Futures of Marketing, 1997, 67-93.

Granovetter, M. (1985). Economic action and social structure: The problem of embeddedness. American journal of sociology, 91(3), 481-510.

Combs,J.G, Ceook, T.R \& Shock, C.L., (2005) The dimensionality of organizational performance and its implications or strategic management research, Research methodology in strategic management (pp 259-286), San Diego

Covin, J.G \&Slevin D, P (1986), The Development and Testing of An Organisational-Level Entrepreneurship Scale. In R Robstadt, J.A Hornaday, R.Peterson and K.H. Vesper (ed), Frontiers of Entrepreneurship Research. (pp. 628 -639)., Babson College; Wellesley.

Dess, G.G \& Lumpkin G.T (1996) Clarifying The Entrepreneurial Orientation Construct and Linking It to Performance. Academy of Management Review, 21 (1); $135-172$

Dess,G.G Lumpkin, G.T.,\&Covin, J.G (1997), Entrepreneurial Strategy Making and Firm Performance: Tests of Contingency and Configurational Models. Strategic Management Journal, 18 (9); 677 $-695$

Dollinger,Marc J. (1999), Entrepreneurship : Strategies and Resources. Prentinve Hall, ISBN 0137459939 (Upper Side River, NJ).

Elfring T \& Hu sink W. (2007). Networking by Entrepreneurs : Patterns of Tie Formation in Emerging Organizations. Organization Studies, 28 (12) : 849-872

Evangelista, F.U (1994), Export Performance and its Determinants : Some Empirical Evidence From Australian Manufacturing Firms?' 'Advances in International Marketing, Vol. 6 ; $207-229$.

Granovetter, M (1985). Economic Action and Social Structure : A Theory of embeddedness. American Journal of Sociology, 91, 481 -510.

Hite J.(2005), Evolutionary Processes and Paths of relationally embedded network ties in emerging entrepreneurial firms. Enterpreneurship Theory and Practice $29: 113-44$.

Innovations. Journal of Marketing, Vol.69 (April), pp.42-60

Hortovanyi, Lilla (2009), Entrepreneurial Management in Hungarian SMEs, Corvinus, University of Budapest. Budapest.

Zahra, S.A.(1991). Predictors and financial outcomes of corporate entrepreneurship: An explorative study., Journal of Business Venturing, 6 ; 259 - 285

Zhou K.Z., Chi Kin Yim and David K. Tse, (2005).The Effect of strategic Orientations onTechnology and Market-Based Breakthrough

Kao,R.W.Y., Kao, K.R \& Kao, R.R (2002) Entrepreneurialism : A Philosophy an a Sensible Alternative to The Market Economy. London: Imperial College Press.

Larson A, Starr JA. (1993). A network model of organizationformation. Entrepreneurship Theory and Practice, 17 (4); $5-18$

Lee D Y and Tsang EWK, (2001), The Effect of Entrepreneurial Personality, Background and Network Activities on Venture Growth, Journal of Management Studies, 38 - 4 , 583 -602

Naver, J.C. and Slater S.F., 1990. The Effect of Market Orientation On Business Profitability, 


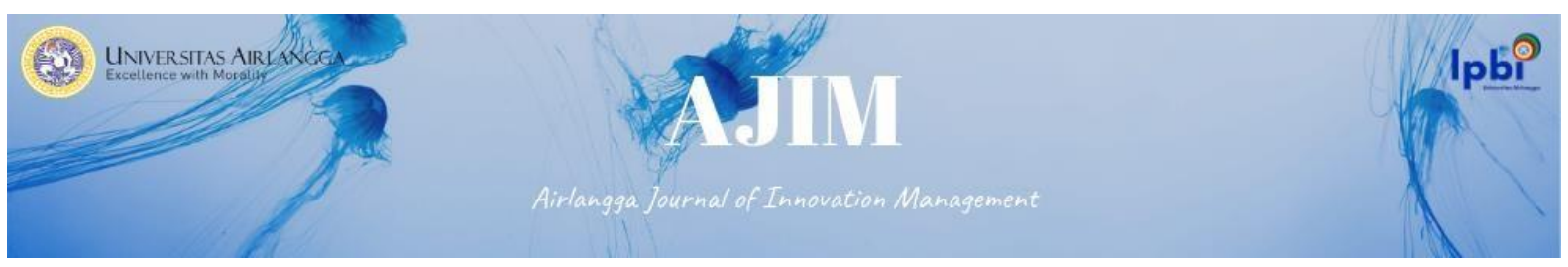

Journal of Marketing, 54 (October), pp 20-25

Quince, T (2003), Entrepreneurial Orientation and Entrepreneurship Intentions and Objectives.

ESRC Centre of Business Review. University of Cambridge. Working Paper no. 271

Smart,D.T\&Conant.,J.S., (1994), Entrepreneurship Orientation, distinctive marketing competencies and organizational performance. Journal of Applied Business Research, 10 (3)

Terziovski, M. (2002). Achieving performance excellence through an integrated strategy of radical innovation and continuous improvement. Measuring business excellence

Timmons J.,(1994),New Venture Creation, $4^{\text {th }}$ ed. Burr Ridge, IL ; Irwin

Undang-UndangRepublik Indonesia No.20, Tahun 2008 TentangUsaha Mikro Kecil dan Menengah Industri Kecil.

Voerman J.A., (2003), The Export Performance of European SME's Labyrint Publication, Netherland

Wiklund, J. (1999). The sustainability of the entrepreneurial orientation-performance relationship. Entrepreneurship theory and practice, 24(1), 37-48.. 